\title{
PECULIARITIES OF THE SEASONAL VARIABILITY OF THE EXTERNAL THERMAL BALANCE AND ITS COMPONENTS ON THE SURFACE OF THE ATLANTIC OCEAN
}

\author{
Yu. V. Artamonov, N.P. Bulgakov, P.D. Lomakin, E.A. Skripaleva, N.A. Timofeev, \\ A.V. Yurovsky
}

Marine hydrophisical institute, Sebastopol, e-mail: ocean@mhi2.sebastopol.ua/Fax:380(0692)444253

\begin{abstract}
The results of the investigations of the peculiarities of spatial distribution and seasonal variability of the external heat budget on the surface of the Atlantic Ocean and its components - net radiation budget and latent and sensible heat fluxes, are presented. It is shown that maximum values of the radiation balance are observed on the tropical peripheries of the subtropical centers of high atmospheric pressure in both hemispheres. Extreme values of the sensible and latent flux are in good correlation well with the wind field parameters in the tropical zone of the ocean and in the area of the Antarctic Circumpolar currents as well as with the characteristics of the meridian large-scale currents. Maximum of seasonal variations of external heat balance are characteristic of the Gulf Stream zone, the western Southern subtropical anticyclonic circulation and the Falkland current area. The study was carried out using up-to-date satellite data sets.
\end{abstract}

Key words: external heat budget, net radiation budget, latent and sensible heat fluxes, seasonal variability.

Особенности внутригодовой изменчивости внешнего теплового баланса и его составляющих на поверхности Атлантического океана Ю.В. Артамонов, Н.П. Булгаков, П.Д. Ломакин, Е.А. Скрипалева, Н.А. Тимофеев, А.В. Юровский

Реферат. Представлены результаты исследований особенностей пространственного распределения и сезонной изменчивости внешнего теплового баланса на поверхности Атлантического океана и его компонентов - радиационной составляющей и составляющей, связанной с турбулентным обменом (поток явного тепла и скрытая теплота испарения). Показано, что максимальные значения радиационного баланса наблюдаются на тропических перифериях субтропических центров высокого атмосферного давления в обоих полушариях. Экстремальные значения составляющей, связанной с турбулентным обменом, хорошо коррелируют с параметрами поля ветра в тропической зоне океана и в области Антарктического Циркумполярного течения, а также с характеристиками меридиональных крупномасштабных течений. Максимальные сезонные вариации внешнего теплового баланса характерны для зоны Гольфстрима, западной части Южного субтропического антициклонического круговорота и района Фолклендского течения. Работа выполнена на базе современных массивов спутниковых наблюдений.

Особливості внутрішньорічної мінливості зовнішнього теплового балансу та його складових на поверхні Атлантичного океану Ю.В. Артамонов, М.П. Булгаков, П.Д. Ломакін, О.О. Скрипальова, М.А. Тімофеєв, О.В. Юровський

Реферат. Представлено результати досліджень особливостей просторового розподілу і сезонної мінливості зовнішнього теплового балансу на поверхні Атлантичного океану та його компонентів - радіаційної складової і складової, пов'язаної з турбулентним обміном (потік явного тепла і схована теплота випару). Показано, що максимальні значення радіаційного балансу спостерігаються на тропічних периферіях субтропічних центрів високого атмосферного тиску в обох півкулях. Екстремальні значення складової теплового балансу, пов'язаної з турбулентним обміном, добре корелюють 3 параметрами поля вітру в тропічній зоні океану та в області Антарктичної Циркумполярної течії, а також з характеристиками меридіональних великомасштабних течій. Максимальні сезонні варіації зовнішнього теплового балансу характерні для зони Гольфстріму, західної частини Південного субтропічного антициклонічного круговороту і району Фолклендської течії. Робота виконана на базі масивів сучасних супутникових спостережень.

\section{Introduction}

Investigations of variability of the heat balance components of oceans and seas are important for understanding the processes of the ocean-atmosphere interaction. Heat balance essentially affects the water masses formation, frontal interfaces and current regimes. Due to the heat redistribution between the low and high latitudes by the oceanic currents systems, various ocean regions influence the climate in different ways. The papers by Timofeev (1970, 1983) and Strokina (1989) consider long-term monthly values of the thermal budget characteristics of the World Ocean surface averaged 
over 5-grade squares. Being so roughly averaged, regional features' resolution appeared far from sufficient. The task of the proposed paper consists in a more detailed research of the features of spatial distribution and regularities of variability of the intra-year cycle of the external heat balance of the Atlantic Ocean surface and its components - the radiation component and the component relating to the turbulent exchange, i.e. the latent and sensible heat fluxes.

\section{Data and method}

In the present work monthly averaged characteristics of the external heat balance of the Atlantic Ocean surface and its components in two-grade trapezes for the water area located between the parallels $40^{\circ} \mathrm{N}$ and $65^{\circ} \mathrm{S}$ calculated by N.A.Timofeev and A.V.Jurovsky (1999) based on the modern arrays of satellite observations were used.

Analyzed fields of the heat balance components are determined using following expressions.

The total amount of heat energy $\left(\mathrm{MJ} / \mathrm{m}^{2} /\right.$ day) received (sign plus) or given up (sign minus) by the ocean through its surface makes the external heat balance $B_{o}=R_{n}-(H+L E)$.

The radiation balance $\left(R_{n}\right)$ on the water surface $\left(\mathrm{MJ} / \mathrm{m}^{2} /\right.$ day) is calculated using the satellite data by the formula:

$R_{n}=\left\{Q_{H}\left(0.94+\frac{0.06 \sin h-0.0376}{\sin h+0.04} \cdot \mu\right)-\left[6.8-0.31 t+0.017 t^{2}-0.00037 t^{3}+0.5\left(t-t_{a}\right)\right]\right\} \cdot \mu$,

where $\quad \mu=\left(A_{\max }-A_{c n}\right) /\left(A_{\max }-A_{c}\right)=\left(F_{c n}-F_{\min }\right) /\left(F_{c}-F_{\min }\right) ; A_{c n}$ is the albedo of the oceanatmosphere system (OAS); $\quad F_{c n}$ is the long-wave radiation of OAS; $h$ is the Sun height; $t$ is the ocean surface temperature $(\mathrm{SST}) ; t_{a}$ is air temperature in the near-surface layer; $A_{\max }, A_{c}, F_{\min }, F_{c}$ are the tabulated parameters (Timofeev, Yurovsky, 1999); $Q_{H}$ is the total solar radiation at the normal temperature.

The components related to the turbulent exchange - latent $(L E)$ and sensible $(H)$ heat fluxes $\left(\mathrm{MJ} / \mathrm{m}^{2} /\right.$ day $)$, are determined as following:

$$
\begin{aligned}
& H=(112-0.4 t)(0.0012+0.000075 u)\left(t-t_{a}\right) u, \\
& L E=(172-0.8 t)(0.0012+0.000075 u)\left(e_{w}-e_{a}\right) u,
\end{aligned}
$$

where $e_{w}$ is the saturation elasticity of water vapor; $e_{a}$ is the water vapor elasticity; $u$ is the wind speed module.

Based on these data the monthly averaged maps of distribution of the studied Atlantic water area are constructed. The harmonious analysis permitted to study distributions of the amplitude-phase characteristics of seasonal variability of the ocean external thermal balance. Analysis and interpretation of the results also included the maps of geostrophic circulation calculated in (Artamonov et al., 2001) using the array from (Levitus, Boyer, 1994), horizontal distributions of the ocean surface temperature (SST) (Levitus, Boyer, 1994) and the monthly averaged fields of the wind tangential tension above the oceanic surface (Hellerman, Rosenstein, 1983).

\section{Analysis of the results}

Radiation balance $\left(\boldsymbol{R}_{\boldsymbol{n}}\right)$. Distribution of the radiation balance on the Atlantic Ocean surface within a year is basically of the zonal character (Fig. 1). The highest values of $R_{n}$ (more than 20 $\mathrm{MJ} / \mathrm{m}^{2} /$ day) are observed on the southern and northern peripheries of the zones of high atmospheric pressure of the Northern and Southern hemispheres where the low cloudy weather promotes the maximum inflow of radiant energy to the ocean surface. In the near-equatorial latitudes, especially in the eastern part of the ocean, cloudiness increase results in the considerable reduction of $R_{n}$ up to $14 \mathrm{MJ} / \mathrm{m}^{2} /$ day in the Inter-tropical convergence zone (ITCZ). Decrease of $R_{n}$ due to the growth of the 
cloudiness cover is also observed in the regions of intensive cyclonic activity in the tropical and subtropical latitudes - closer to the African and South American coasts. The smallest values of $R_{n}$ are characteristic of the near-Antarctic waters at the ice edge where its average annual values on the icefree water area do not exceed $6 \mathrm{MJ} / \mathrm{m}^{2} /$ day. On average the values of $R_{n}$ for a year on the whole icefree surface of the Southern Atlantic are positive.
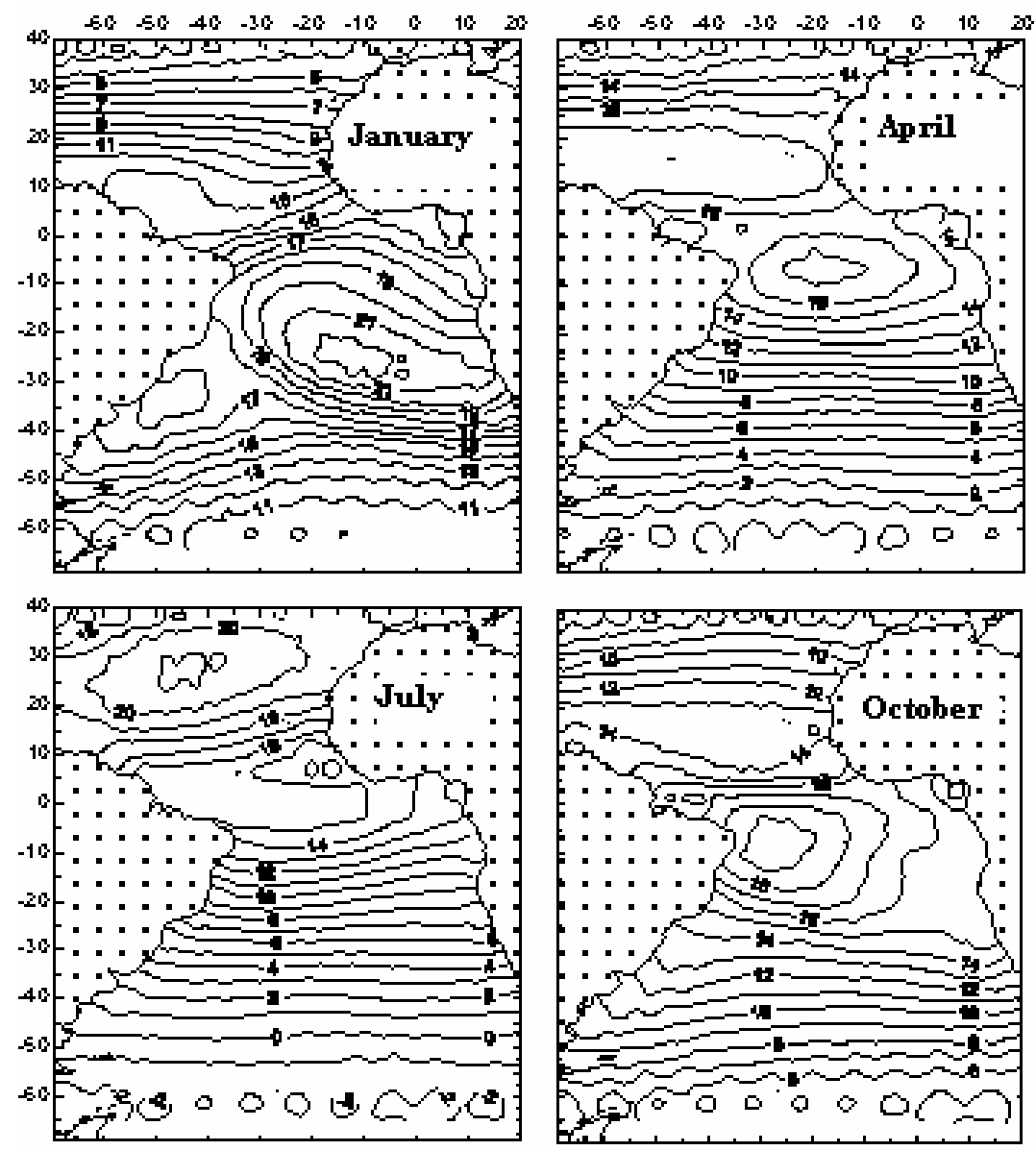

Fig. 1. Radiation balance on the ocean surface $\left(\mathrm{MJ} / \mathrm{m}^{2} /\right.$ day).

Seasonal variations of the radiation balance distribution have the following characteristic features. Since October till February the area of maximum values of $R_{n}$ located southwards of the equator is clearly traced. In October its center is in the area of $10^{\circ} \mathrm{S}$ and $30^{\circ} \mathrm{W}$ (Fig. 1). The area of such high values of $R_{n}$ is formed in July directly on the equator. Then its center moves to the southeast and achieves the extreme southern position $\left(25^{\circ} \mathrm{S}\right.$ and $\left.10^{\circ} \mathrm{W}\right)$ in January. During this season the absolute maximum of $R_{n}$ amounts there to $22 \mathrm{MJ} / \mathrm{m}^{2} /$ day. Further to the east along these latitudes $R_{n}$ is a little bit smaller. In January-May the south-tropical area of high values of the radiation heat inflow moves to the north with the values of $R_{n}$ being decreased. In June-July the maximum of the considered characteristic is located almost at the equator where its values do not exceed 15 $\mathrm{MJ} / \mathrm{m}^{2} /$ day.

Near the South American coast between $25^{\circ}$ and $40^{\circ} \mathrm{S}$ growth of $R_{n}$ is noted from November to February. In January it increases up to $18 \mathrm{MJ} / \mathrm{m}^{2} /$ day. Increase of the radiant energy flow to the 
ocean surface is connected with small cloudiness above the Brazil current in summer in the Southern Hemisphere. In winter when the Brazil current waters weakly penetrate to the south and the cloudiness increases, the values of $R_{n}$ diminish up to $8-6 \mathrm{MJ} / \mathrm{m}^{2} /$ day.

In the Northern Hemisphere in the western tropics the second area of high values of $R_{n}$ is formed in February-March (Fig. 1). In the seasonal cycle it moves to the northeast, and $R_{n}$ grows. In February its center is located near $10^{\circ} \mathrm{N}$ and $55^{\circ} \mathrm{W}$, in June $-25^{\circ} \mathrm{N}$ and $40^{\circ} \mathrm{W}$. Here $R_{n}$ varies from $15 \mathrm{MJ} / \mathrm{m}^{2} /$ day in February up to $21 \mathrm{MJ} / \mathrm{m}^{2} /$ day in July. In this period of a year the southern tropical maximum of $R_{n}$ is the most weakened.

Owing to the variations of the sun angular height, near the equator the radiation balance achieves its maximum values two times per year (March and September): on the days of vernal and autumnal equinoxes.

On the northern boundary of the investigated Atlantic water area, in the Gulf Stream zone $\left(40^{\circ} \mathrm{N}\right)$ the maximum values of $R_{n}\left(17-18 \mathrm{MJ} / \mathrm{m}^{2} /\right.$ day) are observed in July, the minimum ones $(2-3$ $\mathrm{MJ} / \mathrm{m}^{2} /$ day) - in December. On the southern boundary in the Antarctic latitudes, the maximum values of $R_{n}$ (10-11 MJ/m²/day) are characteristic in December-January. In winter in the Southern Hemisphere the radiation balance is negative. The boundary of negative values of $R_{n}$ is located near the parallel $48^{\circ} \mathrm{S}$ and a little bit displaced to the south (up to $54^{\circ} \mathrm{S}$ ) in the west of the ocean. Here the ocean gives away the radiant energy to the atmosphere during 1-2 two months (June-July). Between $60-65^{\circ} \mathrm{S}$ the cold season is longer and the period with negative values of $R_{n}$ lasts from April till August. The minimum values of $R_{\mathrm{n}}\left(-2 \mathrm{MJ} / \mathrm{m}^{2} /\right.$ day $)$ are typical for June-July.

Turbulent exchange (sensible and latent heat fluxes $(\boldsymbol{H}+\boldsymbol{L E})$ ). Monthly average maps of $H+L E$ distribution have a more complex structure as compared to the distribution of $R_{n}$ (Fig. 2). As well as in the case of the radiation balance, in the tropics one can identify two basic areas of the maximum values of $H+L E$. In the Southern hemisphere the maximum heat emission $\left(21 \mathrm{MJ} / \mathrm{m}^{2} /\right.$ day) due to the heat expenses on evaporation and the turbulent exchange is observed in June-July in the region between $10-15^{\circ} \mathrm{S}$ and $20-30^{\circ} \mathrm{W}$. In this period of a year the minimum values of $R_{n}$ and the maximum speeds of the near-surface wind are observed here.

The intra-year variation of zonal and meridian components of the wind tangential tension based on the array data from (Hellerman, Rosenstein, 1983) shows that the maximum wind speeds are characteristic of July. The minimum values of $H+L E\left(13 \mathrm{MJ} / \mathrm{m}^{2} /\right.$ day $)$ are observed here in February when the radiant energy flow is the strongest and the wind speed is minimal.

Seasonal displacements of the south-tropical area of the maximum values of $H+L E$ are insignificant as compared to the change of the center location of the maximum values of $R_{n}$. It is conditioned by the fact that the southeast trade wind axis, with which the extremum $H+L E$ is connected, slightly changes its position in the course of a year.

Near $5^{\circ} \mathrm{S}$ in the field of $H+L E$ there is a frontal zone that is aggravated during the autumnwinter period (March-August) in the Southern Hemisphere (Fig. 2.). At the same time a considerable meridian gradient in the distribution of the zonal component of the wind tangential tension is observed here.

Along the South American coast between the parallels $20^{\circ}$ and $40^{\circ} \mathrm{S}$ there is an area of the increased values of $H+L E$ that is observed in the best way since March till June with its maximum $\left(15 \mathrm{MJ} / \mathrm{m}^{2} /\right.$ day) in April. Comparison with the intra-year variations of $R_{n}$ in this area does not reveal obvious relations with variations of $H+L E$ as the minimal values of $R_{n}$ are observed here almost two months later while the analysis of the water temperature distribution in the ocean upper layer shows that since January till May the Brazil current intensively carries out warm waters from the analyzed water area to the southern latitudes. The inflow of warm waters to the latitudes where the colder air masses are located promotes increase of the values of $H+L E$. This effect grows stronger 
in April-May when the winds of southern directions prevail in this region and the advection of cold air masses from the sub-polar latitudes intensifies.
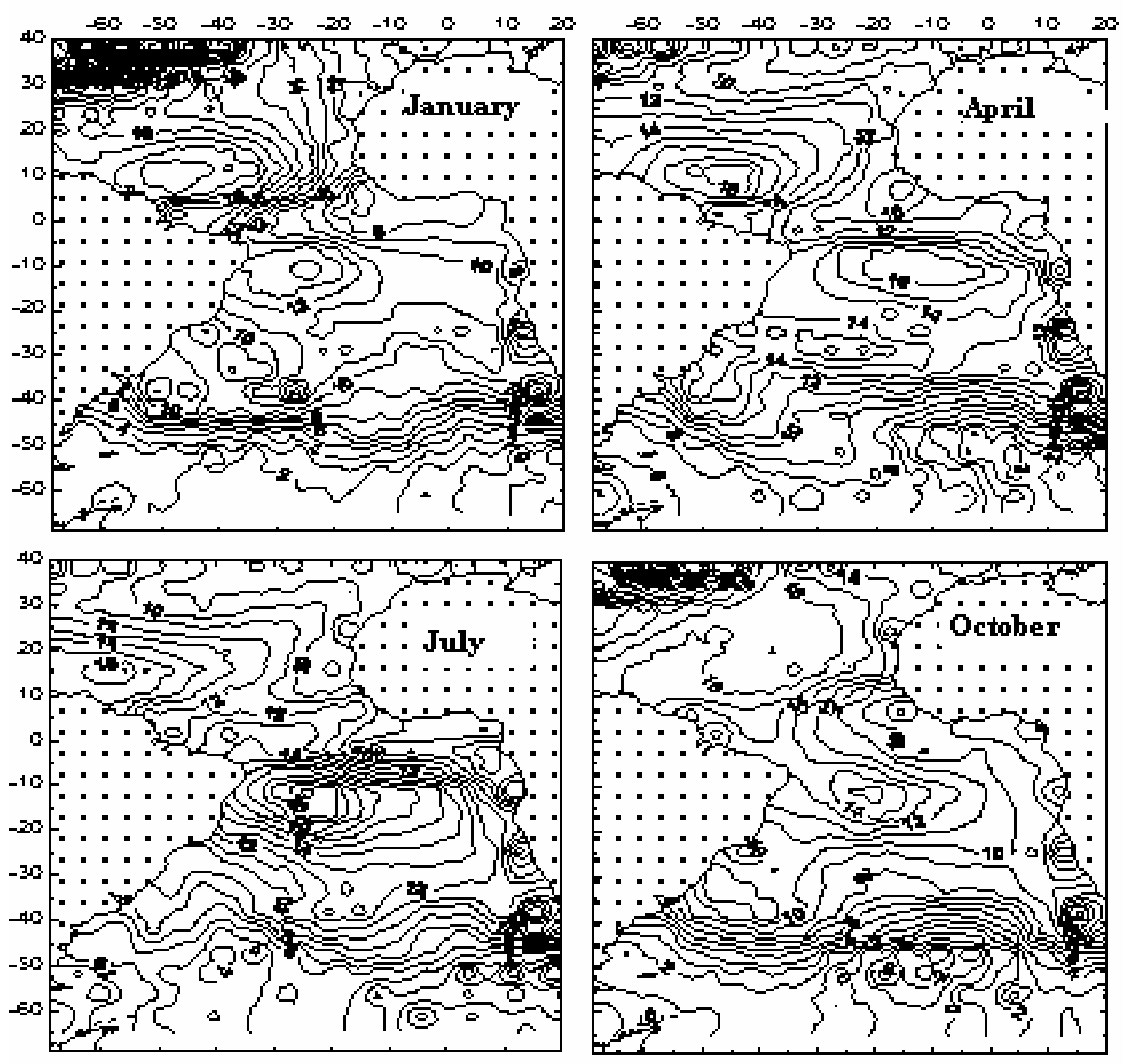

Fig. 2. Monthly average maps of a sum of heat expenses on the turbulent heat exchange in the oceanatmosphere system (sensible and latent heat flux) $\left(\mathrm{MJ} / \mathrm{m}^{2} /\right.$ day $)$.

In tropics the Northern hemisphere maximum heat emission $\left(21 \mathrm{MJ} / \mathrm{m}^{2} /\right.$ day $)$ is observed in January-February between $10-15^{\circ} \mathrm{N}$ and $40-55^{\circ} \mathrm{W}$. During the seasonal cycle this extremum of $H+L E$ moves to the north up to $15-20^{\circ} \mathrm{N}$, in so doing the values of $H+L E$ decrease there. High values of $H+L E$ in this area are due to the strengthening of the northern trade wind (Hellerman, Rosenstein, 1983). Minimum heat emission (14 MJ/m²/day) is characteristic of July-September.

To the south of $40^{\circ} \mathrm{S}$ in the zone of the Antarctic Circumpolar current, significant meridian gradients of $H+L E$ are formed. Their location approximately coincides with that of the axis of zonal transport in the atmosphere. To the east of $10^{\circ} \mathrm{W}$ location of the boundary of sharp meridian gradients of $H+L E$ is marked by the well-pronounced semi-annual signal. To the south of $45^{\circ} \mathrm{S} H+L E$ takes negative values two times a year (May-June and October). The semi-annual signal also is well pronounced in the location of the southern boundary of the zonal western transport in the atmosphere.

Maximum amplitudes of the annual harmonic of $H+L E$ (up to $30 \mathrm{MJ} / \mathrm{M}^{2} /$ day) are typical of the northwestern part of the studied water area. They are characteristic of the Gulf Stream zone where seasonal variations in the wind field are the highest. The maximum amount of heat $\left(35-40 \mathrm{MJ} / \mathrm{m}^{2} /\right.$ day $)$ the ocean loses here during winter of the Northern Hemisphere and the minimum amount (5-10 $\mathrm{MJ} / \mathrm{m}^{2} /$ day) - in summer. 
Semi-annual variations of $H+L E$ with the amplitude up to $5 \mathrm{MJ} / \mathrm{m}^{2} /$ day are observed in the eastern part of the Tropical Atlantic, between the equator and the parallel $10^{\circ} \mathrm{N}$. Semi-annual harmonics in the intra-year variation of the radiant energy coming to the ocean surface and in the variability of the wind field characteristics are noted here (Hellerman, Rosenstein, 1983).

External thermal balance ( $\boldsymbol{B}_{\boldsymbol{o}}$ ). Fig. 3, a shows the annual average distribution of the external heat balance in the ocean. As $R_{n}$ exceeds $H+L E$, in the near-equatorial and partially in the tropical latitudes of both hemispheres the ocean surface receives heat during the whole year. In the higher latitudes heat accumulation by oceanic waters decreases.

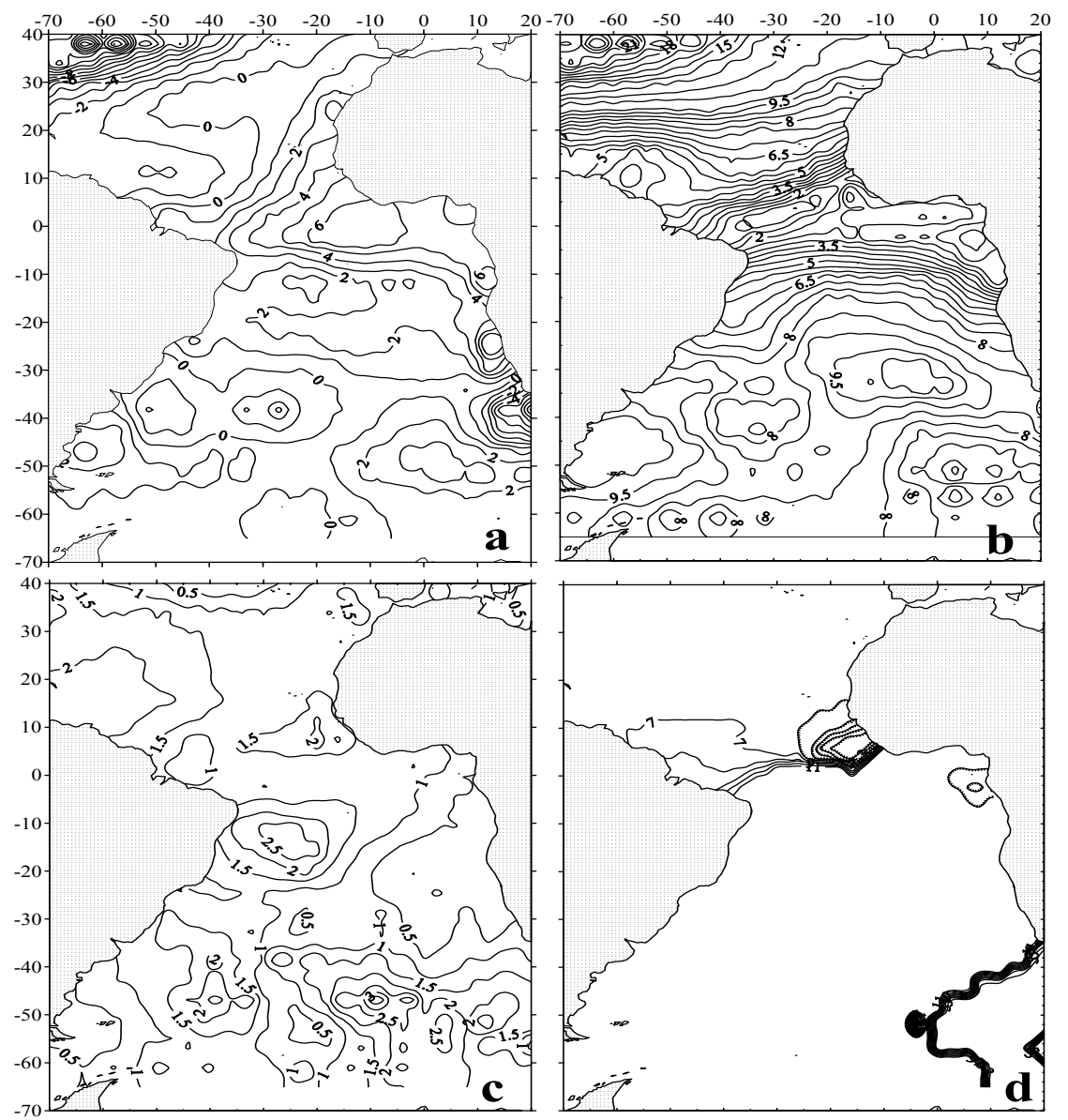

Fig. 3. Distribution of the harmonics of the ocean external heat balance: (a) annual-average balance; amplitude of (b) annual and (c) semi-annual variations and (d) phase of the annual variation $\left(\mathrm{MJ} / \mathrm{m}^{2} /\right.$ day $)$.

The basic maximum of the annual average positive values of $B_{o}\left(>6 \mathrm{MJ} / \mathrm{m}^{2} /\right.$ day $)$ is observed in eastern part of the tropical zone and in the Guinea Gulf. The second extensive area of the increased values of $B_{o}$ is observed between the parallels $45^{\circ}$ and $55^{\circ} \mathrm{S}$. Within the limits of this area there are two local maximums ( $>3 \mathrm{MJ} / \mathrm{m}^{2} /$ day) near the South America coast and in the eastern part of the ocean in those latitudes where the Antarctic Circumpolar current is located. Some increase of the values of $B_{o}$ is also observed in the central parts of subtropical anticyclonic circulations in both hemispheres. 
On the average in the course of a year negative values of $B_{o}$ are found in the Northern Atlantic, in the region of the Gulf Stream and the western boundary layer, in tropics; on the southern periphery of South subtropical anticyclonic circulation, in the zone the currents Agulyas re-circulation, in the central part of the Weddell Sea circulation. Especially significant negative values of $B_{o}$ are marked in the Gulf Stream zone $\left(<-15 \mathrm{MJ} / \mathrm{m}^{2} /\right.$ day) and in the region of a recirculation cell of the current Agulyas $\left(<-9 \mathrm{MJ} / \mathrm{m}^{2} /\right.$ day $)$.

Maximal amplitudes of the annual harmonic $B_{o}$ are characteristic of the Gulf Stream zone ( $>20$ $\mathrm{MJ} / \mathrm{m}^{2} /$ day), the eastern part of the South subtropical anticyclonic circulation $\left(>10 \mathrm{MJ} / \mathrm{m}^{2} /\right.$ day) and the region of the Falkland current ( $>9 \mathrm{MJ} / \mathrm{m}^{2} /$ day) (fig. 3, b). Semi-annual fluctuations of the value $B_{o}$ are marked within the limits of the western boundary layer, in tropics, in the eastern part of the Tropical Atlantic, between the equator and $10^{\circ} \mathrm{N}$, in the tropical zone of South Atlantic between the parallels $10^{\circ}$ and $20^{\circ} \mathrm{S}$ and in the Antarctic Circumpolar current region (fig. 3, c).

Maximum values of $B_{o}$ in the Northern Hemisphere are observed mainly in July, and in the Southern Hemisphere - in December. The line of a season change of the external heat balance is located in the tropical zone approximately along the southern boundary of the intertropical convergence zone (fig. 3, d).

Two areas of violation of this general regularity are noted. One of them is in the Guinean sector between the equator and $10^{\circ} \mathrm{N}$. Here the main maximum of $B_{o}$ falls on April, the second, a weaker one, - on September. Another more extensive area where the main maximum is observed in January is located in the eastern part of the Atlantic sector of Southern Ocean.

Regional peculiarities of seasonal variability of $B_{o}$ and their relation with the gradient largescale water circulation can be understood better after the monthly average maps of the ocean external heat balance (fig. 4) are analyzed.

The characteristic feature of seasonal variability of spatial distribution of $B_{o}$ consists in the changes of the boundary position between the regimes of water heating and cooling in the Northern and Southern hemispheres. Since October till March it is located approximately between the equator and $10^{\circ} \mathrm{N}$ (fig. 4). To the north the ocean gives out heat and gets it to the south. It is noticeable that in the northwest part of the Atlantic tropical zone the period of the upper layer cooling is by a few months longer than that in the central part of the Northern subtropical anticyclonic circulation. Thus, on $20^{\circ} \mathrm{N}$ the heating phase begins in March, whereas on $10^{\circ} \mathrm{N}-$ only in June. It is connected with the fact that in the first half of a year the northern trade wind intensifies and maximum heat emission to the atmosphere due to the sensible and latent flux is observed. In the middle of a year when the values of $H+L E$ decrease the ocean receives heat.

In the first half of a year in the Northern Hemisphere the distribution of $B_{o}$ qualitatively repeats the distribution of $H+L E$. It is connected with the fact that on the major part of the ocean water area the radiant energy inflow is insignificant, and heat for evaporation and turbulent heat exchange with the atmosphere is spent basically due to heat power resources of the oceanic currents. Thus an absolute maximum of heat inflow from the under-laying layers to the ocean surface is observed in the Gulf Stream zone (more than $40 \mathrm{MJ} / \mathrm{m}^{2} /$ day).

In the Southern Atlantic in the zone of the Brazilian and Falkland currents merging and in the region of the Weddell Sea circulation, the values of $B_{o}$ become negative in March, and in April practically the whole water area of the Southern Atlantic (to the south of $5-10^{\circ} \mathrm{S}$ in the west and $15^{\circ} \mathrm{S}$ in the east) gives out heat to the atmosphere. Since May till August the boundary between positive and negative values of $B_{o}$ is manifested in a form of the high-gradient frontal zone located between the parallels $5^{\circ}$ и $10^{\circ} \mathrm{S}$. Its location coincides with the frontal zone in the field $H+L E$ (fig. 2) and with the well pronounced geostrophic flow of the western direction (the central branch of the Southern trade current) in the field of dynamic heights. To the north of the frontal zone between the equator and $5^{\circ} \mathrm{S}$, to the east of $30^{\circ} \mathrm{W}$ the local maximum of $B_{o}$ is formed in May and observed till December (fig. 4). During this period the values of $H+L E$ near the equator are low. The well pronounced 
equatorial temperature minimum and the shallow gully of the dynamic relief that testify to the intensification of the Lomonosov current and its elevation to the surface, are also noted.
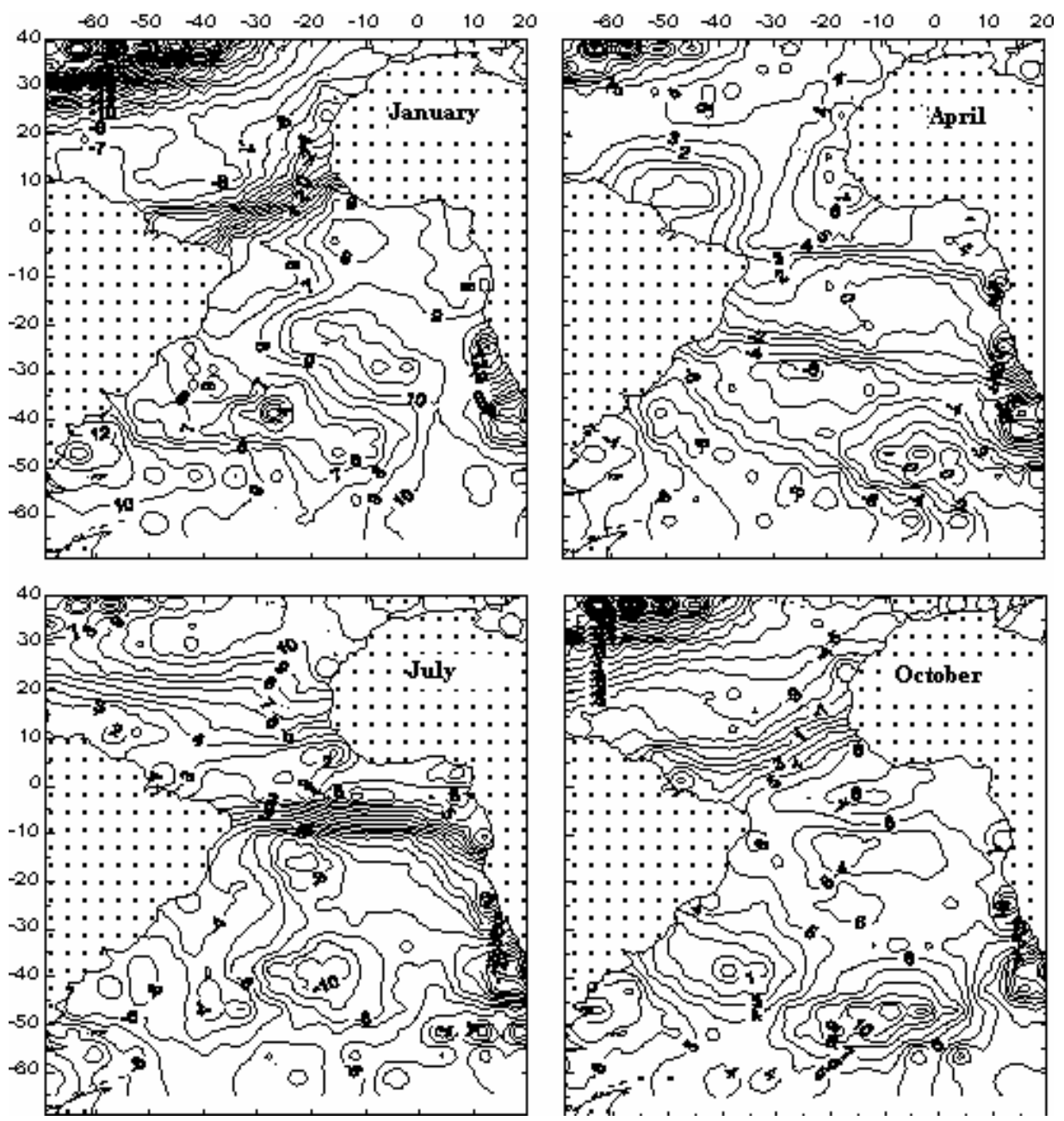

Fig. 4. External heat balance of the ocean $\left(\mathrm{MJ} / \mathrm{m}^{2} /\right.$ day $)$.

In November-January in the eastern half of the ocean, approximately between the parallels $20^{\circ}$ and $30^{\circ} \mathrm{S}$, the area of the increased values of heat inflow to the ocean is distinguished. Intensive heating of these waters is promoted by the high values of $R_{n}$, and rather weak winds during this period provide low values of $H+L E$. To the southwest from this area the values of $B_{o}$ decrease. The analysis of the water temperature distribution on the ocean surface shows that during these months the cold water within the system of the Bengel and Southern trade currents is brought from the south. To the southwest, warm waters brought by the Brazil current from the west to the east is observed.

The boundary of two oppositely directed water flows coincides with the boundary where the meridian component of the wind tangential tension changes its sign. During this period of a year it is in its extreme northern position. The Southern equatorial countercurrent is poorly manifested in this period.

In May-August the Southern equatorial countercurrent intensifies (the dynamic relief crest near $10^{\circ} \mathrm{S}$ is better pronounced) that results in the intensive coming of warm waters on this latitude to the 
east and in the increase of heat consumption for evaporation. On the other hand, strengthening of the southern trade wind is observed here. That is accompanied by the increase of heat consumption for the turbulent exchange with the atmosphere. As a result, $H+L E$ exceeds heat amount coming due to the solar radiation. Since May till August the local extremum of negative values of $B_{o}$ (up to 10 $\mathrm{MJ} / \mathrm{m}^{2} /$ day) is formed here.

Significant heat return by the under-laying layers through the ocean surface to the atmosphere is observed in the zone of the Brazilian and Falkland currents merging, in the South Atlantic current and in the zone the Agulyas current recirculation.

Maximum heat return in the zone of the Brazilian and Falkland currents merging is typical for May-June (10-12 MJ/m²/day). In the given area maximum wind speeds and maximum values of $H+L E$ are observed in this period of a year. Thus minimum of $R_{n}$ occurs approximately a month later - in July-August, and SST minimum - in August-September. In other words, the extreme negative values of $B_{o}$ are conditioned by warm water advection to the south by the Brazil current in the conditions of maximum wind speeds. The ocean receives the greatest amount of heat (10-12 $\mathrm{MJ} / \mathrm{m}^{2} /$ day) in January in the region of the Falkland current above the Patagonian shelf. During this period the maximum flow of radiant energy and minimal wind speeds are observed. In the central part of the region in the area of the South Atlantic current the ocean gives out the maximum amount of heat (up to $10 \mathrm{MJ} / \mathrm{m}^{2} /$ day) in May-July when minimum values of $R_{n}$ are noted. It is typical that in the seasonal cycle the extremums of $B_{o}$ and $H+L E$ occur first between the parallels $50^{\circ}$ and $60^{\circ} \mathrm{S}$ in April. Then they move to the north and in May-July they are located between the parallels $30^{\circ}$ and $40^{\circ} \mathrm{S}$. Similar displacement is observed in location of the maximum of the zonal component of the wind tangential tension.

In the zone of the Agulyas current recirculation $\left(40^{\circ} \mathrm{S}\right)$ two maximums of heat emission - in April (up to $12 \mathrm{MJ} / \mathrm{m}^{2} /$ day) and in July (up to $16 \mathrm{MJ} / \mathrm{m}^{2} /$ day) are observed. The main maximum of the heat inflow to the ocean (up to $6 \mathrm{MJ} / \mathrm{m}^{2} /$ day) is noted in February. The intra-year variation of the zonal component of the wind tangential tension and the values of $H+L E$ contain a semi-annual harmonic. It is typical that on the water area between the parallels $50-55^{\circ} \mathrm{S}$ warm season lasts almost two months longer, and in winter the minimum heat emission is observed. Here in the course of the major part of a year, except for September-November, the values of $H+L E$ are positive, and the wind speed maximum is located to the north of these latitudes. SST maps and the schemes of dynamic topography show that in these latitudes the southern boundary of the maximum meridian temperature gradient that coincides with the southern boundary of the Antarctic Circumpolar current is located. Here during the major part of a year, northern winds prevail. They bring warm air to the water area occupied by cold Antarctic water masses. On the boundary of cold waters the ocean receives heat practically within the whole year. To the south where the air masses lose their heat supply this effect is not manifested. Similar seasonal variability of $B_{o}$ on the boundary of cold waters is observed on the whole water area of the Atlantic sector of the Southern ocean to the east of $10^{\circ} \mathrm{W}$.

The above described peculiarity of seasonal variability of the value $B_{o}$ is not manifested in the western half of the ocean where the boundary of cold Antarctic water masses is located much to the south $\left(55-63^{\circ} \mathrm{S}\right)$ and the winds with the southern component prevail.

\section{Conclusion}

Based on the array of monthly average climatic data of satellite observations investigated are the regularities of spatial distribution and seasonal variability of external heat balance $B_{o}$ of the Atlantic Ocean surface and its components - radiation component $R_{n}$, turbulent exchange $H+L E$ (the sensible and latent flux).

It is shown that distribution of the radiation balance $R_{n}$ is mainly of a zonal character. Its maximum values are observed on the tropical peripheries of the subtropical centers of high atmospheric pressure in both hemispheres. Minimum $R_{n}$ is typical of the water areas located near the 
Antarctic ice edge. On the prevailing part of the Atlantic Ocean seasonal fluctuations of $R_{n}$ are characterized by harmonic of the annual period with the maximum amplitude $10-15 \mathrm{MJ} / \mathrm{m}^{2} /$ day in the tropical zone. In the equatorial area the intra-year cycle of fluctuations of $R_{n}$ contains harmonic of the semi-annual period with the amplitude about $5 \mathrm{MJ} / \mathrm{m}^{2} /$ day.

Distribution of the heat balance component connected with the turbulent exchange, and its seasonal variations are more complex in comparison with the changes of $R_{n}$. Extreme values of $H+L E$ correlate well with the wind field parameters in the tropical zone of the ocean and in the area of the Antarctic Circumpolar currents and with the characteristics of the meridian large-scale currents. The maximum amplitudes of the annual harmonic $H+L E$ are observed in the northwest part of the Atlantic, in the Gulf Stream zone $\left(30 \mathrm{MJ} / \mathrm{m}^{2} /\right.$ day), in the northern and southern tropics (10 $\mathrm{MJ} / \mathrm{m}^{2} /$ day). Well pronounced semi-annual harmonic in the seasonal cycle of variability of $H+L E$ with the amplitude $2-3 \mathrm{MJ} / \mathrm{m}^{2} /$ day is observed between the equator and the parallel $10^{\circ} \mathrm{N}$, in the eastern part of the Antarctic sector of the Atlantic and in the field of the Antarctic Circumpolar current.

Maximum seasonal variations of external heat balance are characteristic of the Gulf Stream zone (amplitude $\approx 22 \mathrm{MJ} / \mathrm{m}^{2} /$ day), the western part of the Southern subtropical anticyclonic circulation and the Falkland current area (amplitude $\approx 10 \mathrm{MJ} / \mathrm{m}^{2} /$ day). Minimal annual fluctuations of $B_{o}$ with the amplitude 1-2 $\mathrm{MJ} / \mathrm{m}^{2} /$ day are noted in the region of the Inter-tropical convergence zone and in the Guinean Gulf. The role of the semi-annual signal in the seasonal variability of the ocean surface heat exchange with the under-laying layers is most significant in the western boundary layer, in the Guinean sector of the Tropical Atlantic, on the northern periphery of the Southern subtropical anticyclonic circulation and in the region of the Antarctic Circumpolar current.

\section{References}

Timofeev N.A. Atlas teplovogo balansa okeanov. - Sevastopol: MGI AN USSR, 1970. - 88 p.

Timofeev N.A. Radiatsionny rezhim okeanov. - Kiev: Nauk. Dumka, 1983. - 247 p.

Strokina L.A. Teplovoi balans poverkhnosti okeanov. Spravochnoe posobie. - L.: Gidrometeoizdat, 1989. - 48 p.

Timofeev N.A., Yurovsky A.V. Dlinnovolnovoe izluchenie v kosmose kak indikator radiatsionnogo rezhima okeanov // Issledovanie Zemli iz kosmosa. - 1999. - № 1. - P. 9-17.

Timofeev N.A., Yurovsky A.V. Anomalii radiatsionnogo balansa okeanov $v$ period maksimuma El'-Nin’yo // Issled. Zemli iz kosmosa. - 1999. - № 5. - P. 32-41.

Levitus S., Boyer P.T. World Ocean Atlas. U.S. CD-ROM Data Sets. // National Oceanographic Data Center, Ocean Climate Laboratory, Washington, D.C, June, 1994.

Artamonov Yu.V., Bulgakov N,P., Lomakin P.D. Tsirkulyatsiya vod deyatel'nogo sloya Yuzhnoi Atlantiki // Preprint, MGI NANU, Sevastopol, 2001. - 86 p.

Artamonov Yu.V., Bulgakov N.P., Lomakin P.D. Geostrogicheskaya tsirkulyatsiya vod yuzhnoi chasti Atlanticheskogo okeana i ee sezonnaya izmenchivost' // MGZh. - 2002. - № 3. - P. 4349.

Hellerman S., Rosenstein M. Normal monthly wind stress over the World Ocean with error estimate // J. Phys. Oceanogr. - 1983. - 13. - P. 1093-1104. 